10 Rielly MF. The nature and causes of hockey injuries. A five-year study. Athletic Training 1982; 17: 88-90.

$11 \mathrm{Sim} \mathrm{FH}, \mathrm{Chao}$ EJ. Injury potential in modern ice hockey. Am J Sports Med 1978; 6: 378-84.

12 Sim FH, Simonet WT, Melton LJ, Lehn TA. Ice hockey injuries. Am I Sports Med 1987; 15: 30-40.

13 Sutherland GW. Fire on ice. Am J Sports Med 1976; 4: 264-9.
14 Tator $\mathrm{CH}$, Edmonds VE. National Survey of spinal injuries in hockey players. Can Med Assoc J 1984; 130: 875-80.

15 Tator, CA, Ekong CEU, Rowed DW et al. Spinal injuries due to hockey. Can I Neurol Sci 1984; 11: 34-41.

16 Vinger PF, Hoerner EF (eds) 'Sports Injuries; The unthwarted epidemic. Boston: John Wright \& PSG Inc, 1982.

\title{
News
}

\section{Sink or Swim?}

It is reported that the Minister of Education's Advisory Committee on Physical Education and Sport is to recommend that all children be taught to swim at least $25 \mathrm{~m}$ by the age of 11 . This would encourage an effective sport for mass fitness and be a major step forward in preventive medicine as drowning has always caused more deaths in the UK than all other sports injuries put together. In the last 3 years almost 200 British children under 15 have drowned; 80 per cent were unable to swim (The Guardian, 20 February 1991). Any doctor who has struggled in vain to resuscitate a drowned child will have wondered why this obvious recommendation has not long been public policy.

It is with dismay that we read of the Minister's negative response to this recommendation and hope that reconsideration will lead to the saving of young lives.

\section{L-Tryptophan and Eosinophilia Myalgia Syndrome (EMS)}

The Department of Health has banned the sale of all foods containing added tryptophan (except under strictly defined medical prescription). This follows the discovery that EMS may occur in response to very small amounts of tryptophan (and/or one of its unidentified contaminants), often in 'health' supplements in which its presence may be hidden in such words as 'amino-acid mix'.

The EMS may include myalgia, arthralgia, fever, oedema and rash, with eosinophilia usually over $2000 / \mathrm{mm}^{3}$.

Source: Department of Health Circular PL/CMO(90)6

\section{Asian Federation of Sports Medicine}

We warmly congratulate our colleagues on their foundation of the Asian Federation of Sports Medicine under the aegis of FIMS. We are delighted that the founding officers are all members of BJSM's Editorial Board, Professor Qu Mian-Yu (President), Dr Nishat Mallick (Vice President) and Dr Kai Ming Chan (Secretary). 